\title{
Article \\ Evidence-Based Market Overview of Incentives and Disincentives in Electric Mobility as a Key to the Sustainable Future
}

\author{
Gabriel Ayobami Ogunkunbi (D), Havraz Khedhir Younis Al-Zibaree (D) and Ferenc Meszaros * (D) \\ Department of Transport Technology and Economics, Faculty of Transportation Engineering and Vehicle \\ Engineering, Budapest University of Technology and Economics, 1111 Budapest, Hungary; \\ ogunkunbi@edu.bme.hu (G.A.O.); havraz.zibaree@edu.bme.hu (H.K.Y.A.-Z.) \\ * Correspondence: meszaros.ferenc@kjk.bme.hu
}

Citation: Ogunkunbi, G.A.;

Al-Zibaree, H.K.Y.; Meszaros, F.

Evidence-Based Market Overview of

Incentives and Disincentives in

Electric Mobility as a Key to the

Sustainable Future. Future Transp.

2021, 1, 290-302. https://doi.org/

$10.3390 /$ futuretransp1020017

Academic Editor: Armando Cartenì

Received: 4 May 2021

Accepted: 4 August 2021

Published: 9 August 2021

Publisher's Note: MDPI stays neutral with regard to jurisdictional claims in published maps and institutional affiliations.

Copyright: (c) 2021 by the authors. Licensee MDPI, Basel, Switzerland. This article is an open access article distributed under the terms and conditions of the Creative Commons Attribution (CC BY) license (https:// creativecommons.org/licenses/by/ $4.0 /)$.

\begin{abstract}
Electric mobility is one of the key technologies that may contribute to tackling externalities especially in the fight against climate change, and consequently in achieving sustainable transportation. Among the different electric vehicle (EV) technologies, battery electric vehicles (BEVs) constitute a strong option for future transportation. Despite the large investments made in the EV industry and the large-scale promotion of electric mobility through several policy measures in the last decade, this market segment is still underrepresented in the total automotive market. The available evidence indicates that there is a remarkable gap between the expectations and experiences in applying the measures. This study investigates the available measures that, directly or indirectly, may contribute to the future success of the BEVs. The authors categorize the available measures (financial incentives, non-financial incentives, disincentives) and highlight the possible cross-effects between them through a descriptive analysis. The main finding of this study is that, as there are synergies between the different measures, decision makers need a complex approach to excavate the market mechanism and implement effective and efficient policy measures.
\end{abstract}

Keywords: battery electric vehicles; electric mobility; policy measures; sustainability

\section{Introduction}

Due to the high adverse risks associated with traffic-related air pollution, climate change, and other effects of transport, it has become important to set the transport sector on a sustainable course for the sake of today and the future. Efforts are being geared towards a low-carbon development pathway for global climate change mitigation to avoid the most severe climate change and keep the global temperature rise below $2{ }^{\circ} \mathrm{C}$, as agreed by nations under the United Nations Framework Conventions on Climate Change (UNFCCC) in the Paris Agreement [1]. Based on this agreement, developed nations will have to decarbonize their transport sector up to $80 \%$ by 2050 , while developing and emerging countries will have to curb growth up to $170 \%$ by 2050 , which will require substantial policy actions and complex strategies [2]. Transportation has been under major scrutiny as it accounted for $24 \%$ of carbon dioxide emissions from fuel combustion in 2019 , with road vehicles accounting for about three quarters of these emissions due to the heavy dependence on vehicles powered by fossil fuels for mobility needs [3].

The deployment of alternative fuel infrastructure and other means of road transport with less or zero tailpipe emissions has been one of the major pathways towards a more sustainable transport system. Electric vehicles of all types, including battery electric vehicles (BEVs), plug-in hybrid electric vehicles (PHEVs), hybrid electric vehicles (HEVs), and electric power-assisted personal mobility vehicles (e-PMVs), have been under the spotlight as they are key alternatives to internal combustion engine vehicles (ICEVs) for improving energy efficiency, mitigating local air pollution, reducing carbon dioxide 
emissions, diversifying transportation fuel sources, and integrating renewable energy into the power system [4-8].

Like every other technological shift, the transition from conventional vehicles to electric vehicles has not been without its fair share of hiccups and challenges and may require a long time to be completed. However, the climate emergency has made time a luxury. Strategic plans for spurring the EV market have consequently become essential. Governments at all levels have thus developed different programs and routes to promote EV adoption, which revolve mainly around incentivizing the EV market or disincentivizing the conventional vehicle market. Consequently, PEVs (plug-in electric vehicles), including BEVs and PHEVs, have enjoyed a tremendous boost in sales in the alternative fuel vehicle market. The difference between the two types of PEVs is that PHEVs run on a batterypowered electric motor with an internal combustion engine present as backup, so it can drive on either electricity or gasoline, whereas the BEV solely depends on the chemical energy stored in its rechargeable battery packs for propulsion.

$\mathrm{BEVs}$ are considered more friendly to the environment because they produce zero tank-to-wheel emissions, whilst the upstream pollution or well-to-tank they produce is largely dependent on the electricity source used for battery charging and the energy intensity of manufacturing [9-11]. Hence, the overall pollution is less severe if the power generation is sourced from renewable energy resources. Unlike BEVs, the environmental gains derived from PHEVs depend on the distance driven while in electric mode. A study has reported that PHEV fuel consumption and tailpipe $\mathrm{CO}_{2}$ emissions during real-world driving, on average, are approximately 2-4 times higher than type-approval values [12]. This is attributed to the small battery capacities, underpowered electric motors, and the absence of fast charging capabilities in some models, making it practically difficult for them to be driven properly on zero emission mode. Moreover, BEVs allow for the diversification of transportation energy sources since electricity can be produced from a variety of conventional and renewable technologies.

Unfortunately, BEVs have limitations, and their adoption is hampered by several barriers compared to their competitors with internal combustion engine components. BEVs have high purchase prices, more limited ranges, longer refueling times, and less public infrastructure, i.e., refueling opportunities, compared to fossil-fueled vehicles [13-15]. These hurdles have necessitated the need for policy instruments and strategies specifically crafted for BEVs to accelerate their uptake compared to other alternative fuel vehicles and increase their market share in the automobile market, to harness the social benefits of GHG (greenhouse gas) emissions reduction in pursuit of sustainable road transportation.

This study builds on the rich body of literature on market incentives as a strategy to boost the adoption of electric vehicles, to provide an evidence-based market overview focused specifically on battery electric passenger cars. It enumerates the major hurdles to market penetration and governmental incentives to boost adoption, establish the interdependencies between them, and expand these to postulate pathways to utilize the synergies to bridge the gap between government expectations, societal experiences, and market realities. The authors identified and categorized the existing measures according to their main attributes as financial incentives (purchase incentives, value-added tax exemption, vehicle registration tax benefits, ownership tax benefits, discounted/free parking, and toll road exemptions), non-financial incentives (charging infrastructure development and access to restricted traffic lanes), and disincentives with respect to conventional vehicles. The timeline of the analysis aims to neglect the recent pandemic years due to their market distorting effects.

The remainder of this paper is organized as follows. Section 2 discusses the main barriers inhibiting the adoption of BEVs in detail. Section 3 provides an evidence-based overview of the different efforts made to boost BEV adoption by different cities and countries using descriptive analysis of existing literature to highlight the impacts of the incentives on BEV adoption. Section 4 discusses the synergies between the different mea- 
sures and how decision-makers can harness these to design and implement effective and efficient policy measures, fostering gains toward a vision of sustainable urban transport.

\section{Barriers Inhibiting Wider Adoption}

With electric mobility recognized to play a prominent role in transforming transportation from its current unsustainable state into an environmentally friendly one, it has been expected that electric vehicles would demonstrate a rapid penetration into the automobile market and enjoy a wide adoption. This, however, has not been the case. Several factors affect the decision of potential EV buyers and subsequently determine the strength of the EV market in general, specifically BEVs within this study's scope. A classification of these factors based on the respective decision-making unit as identified by Biresselioglu et al. [16] is presented in Table 1. While all these factors are important, purchase cost, specific user needs and requirements, limited information and technological uncertainty, and other demographic (country-specific) factors have been identified as the major influencing factors $[17,18]$.

Table 1. Factors influencing EV adoption decision making.

\begin{tabular}{|c|c|c|}
\hline Formal Social Unit & Collective Decision Making Unit & Individual Level Unit \\
\hline Operational features & Attitude towards electric vehicles & Demographics \\
\hline Charging infrastructure & Charging infrastructure & Attitude towards electric vehicles \\
\hline Economic performance & Charging solutions & Environmental values, beliefs, and norms \\
\hline $\begin{array}{l}\text { Regulations, policy } \\
\text { practices, incentives }\end{array}$ & Characteristics of EV use & Social influence and social factors \\
\hline Environmental aspects & - & Regulations, policy practices, incentives \\
\hline+1 & - & $\begin{array}{l}\text { Experience with electric vehicles and general awareness } \\
\text { about EVs }\end{array}$ \\
\hline- & - & Preference, lifestyle, and habits with respect to EV use \\
\hline
\end{tabular}

Source: Biresselioglu et al. [16].

\subsection{Purchase Cost}

Within the existing market conditions and barring all other factors, the cost of a battery electric vehicle is higher than the cost of conventional vehicles. Jozwicka et al. [19] identified this price margin to be up to 10,000 euros. In the existing scenario, consumers often have to pay a premium of up to $100 \%$ for new conventional vehicles, which is highly prohibitive if this culture has to be transferred to the electric vehicle market. Thus, several studies have appropriately identified cost as the major hindrance inhibiting the adoption of electric vehicles while highlighting the battery as the primary component responsible for this cost.

Lithium batteries are considered to be the dominant technology and one of the main reasons behind the high initial price of BEVs. However, scientists are concerned about the availability of lithium and its adequacy to satisfy the rise in demand needed for EV development [20]. A significant increase in demand for lithium recently could lead to a shortage of lithium, which consequently causes an increment in the market price and affects the BEVs market negatively. With the estimate of global known lithium resources under 14 million tons, with $74 \%$ of these located in reserves around South America [21,22], it could be another geopolitical risk to heavily depend on this region for supply as it could birth an oligopoly similar to the global oil market. Significant efforts are being geared toward research and development to reduce the cost of batteries. These efforts have brought about a significant reduction. Battery manufacturing costs have been declining continuously, with an approximately 14\% annual drop in prices between 2007 and 2014 [23].

\subsection{Limited Range and Refueling Time}

Besides the high purchase price limiting the electric vehicle market, limited range and long refueling time are two other prominent concerns. The battery is the only energy 
source for BEVs-unlike PHEVs that can fall back on the combustion energy when the battery charge is depleted-, which limits the trips BEVs are used for and further aggravates the "range anxiety" of users. While the trend is to provide BEVs with improved battery capacity and increased range as a solution on the one hand, they are currently more expensive [24]. However, such vehicles might become more affordable in the future due to the consistent decline in the production cost of lithium-ion batteries [25]. On the other hand, the interdependency between charging time and battery capacity with the electricity load profile is another setback. BEVs with large batteries require less frequent but longer durations for charging, while small batteries need to be charged more frequently with relatively shorter charging events to ensure sufficient energy for future trips. Furthermore, climate adjusting features, such as passenger cooling and heating systems, and battery heating and cooling systems, especially during cold periods, can consume much of the battery capacity, potentially reducing driving range [26,27]. Electric vehicle users will thus need to incorporate these factors into consideration while planning their daily commute or before embarking on long distance trips.

\subsection{Technological Uncertainty}

New technologies are usually associated with many uncertainties, and electric vehicle technology is not an exception, despite its long history of development. Potential users and non-users find many aspects of technological development to be uncertain and yet to reach developmental maturity. With concerns about vehicle range, charging infrastructure availability, and purchase costs already on the horizon, battery life expectancy, resale value, and other unknown ownership risks further compound the uncertainty around electric vehicle adoption and usage.

While the concerns about range, cost, and technological uncertainties constitute a challenge to potential owners of the vehicles, the attitude and response to adoption vary depending on the socio-demographic and socio-economic factors at play. These factors include income, environmentalism, employment ratio, gasoline price, and electricity price [28,29]. Education level could also have an effect to some extent on the decision of the BEVs potential buyers. Many researches, including selected studies [30-33], have investigated the impact of these factors on EV adoption in general, with differing inferences which, altogether, are helpful to strategize approaches to overcome the barriers and incentivize the adoption and market penetration of BEVs.

\section{Incentivizing Market Adoption and Penetration}

Having identified the various barriers limiting the broader adoption of BEVs and hence their low market share, we will now analyze the different types of incentives used to positively stimulate and influence the decision making of potential adopters of electromobility. Evidence of the effects of the stimuli within scientific literature will also be detailed.

\subsection{Financial Incentives}

Although EVs have been proven to lessen air pollution compared to ICE vehicles, consumers will not readily switch to EVs as they would rather maximize private utility than incur costs for social gains with benefits that are not apparent in the short term [34]. Owing to the prohibitive costs of EV batteries with the lower gas prices and improved fuel efficiency of modern internal combustion engines, conventionally fueled vehicles have an edge in ownership cost implications over BEVs, particularly at the point of purchase. Therefore, it becomes imperative and logical to offer incentives to lower the cost barrier of EVs and make them financially attractive and viable for potential adopters. Financial incentives are economic instruments aiming to influence the adoption of EVs by either offering grants, rebates, discounts, or through exemption from financial obligations to the government or a relevant agency. Financial incentives could be offered as a once-off deal 
(direct measures) or could be recurrent depending on the framework of the supporting policy (indirect measures) [35].

\subsubsection{Purchase Incentives}

Purchase incentives are offered in the form of grants or purchase discounts by the government or organization working on reducing negative transport externalities to encourage more potential buyers and, consequently, to spur the EV market. Aside from direct purchase discounts, they are also offered in the form of cash rebates, low-interest financing, special leases, and marketing support. A stated preference study [36] in China validates this approach, concluding that consumers are more sensitive to the vehicle purchase price compared to other common types of incentives. Therefore, it is one of the most common economic instruments used to stimulate the penetration of EVs in the fleet of urban vehicles in many European countries. In Germany, the potential buyer is granted 40,000 euros and 3000 euros, for private and business purposes, respectively. The UK started giving PEV buyers incentives in 2011 to support the ultralow emission vehicle market. In the last seven years, purchase subsidies have reached approximately 500 million pounds (580 million euros), spent on 160,000 ultra-low emission cars. In France and Belgium, the vehicles with a CO2 emission rate between 0 and $20 \mathrm{~g}$ are granted a bonus of 6000 euros, which is about $27 \%$ of the acquisition cost. In Spain and Portugal, the national subsidy is up to 5500 euros and 2250, respectively, for the BEVs, including the passenger and light-duty vehicles. In Austria, there is a purchase subsidy of up to 4000 euros for BEVs, of which the federal government gives 25000 euros and 1500 euros is the additional rebate from the industry. Finland also offers a direct purchase subsidy of 2000 euros for BEVs which cost less than 50,000 euros.

An investigation [37] signaled subsidies at the point of purchase to make BEVs attractive to individuals at the point of decision-making, mainly due to the dissimilar cost distribution in the amounts granted to HEVs, PHEVs, and BEVs. A parallel study [28] also identified the availability of government grant to be highly pivotal for firms that incorporated EVs into their fleet. However, studies [38,39] found the impact of pricereducing subsidies to be limited. Liao et al. [38] suggested that the higher symbolic value attached to higher-priced cars may discourage some potential buyers. At the same time, Huang et al. [39] highlighted that purchase incentives' effectiveness depends mainly on the consumer's bargaining power.

\subsubsection{Value Added Tax (VAT) Exemption}

This incentive exempts the buyer from paying value-added tax or purchase tax. Different countries apply different methods based on their fiscal policy while calculating the tax exemption. For example, in France, the $100 \%$ of the VAT can be recovered on electricity, as in Norway, where the potential buyers are exempt from the VAT. In Austria, the companies owning BEVs are exempted from VAT (eligible for pre-tax deduction), while in Portugal and Netherlands, the tax reduction/exemption is based on $\mathrm{CO}_{2}$ emissions. BEVs are totally exempted from paying tax in the Netherlands.

These exemptions, which effectively reduce the initial price of EVs in general and BEVs specifically since they have zero tailpipe gases, have been confirmed by multiple studies to be a significant predictor of EV adoption [28,40-42]. Notable among these studies by Bjerkan et al. [41], whose survey of about 3400 BEV owners in Norway found VAT exemption as a critical incentive that positively influenced the purchase decision of more than $80 \%$ of the respondents.

\subsubsection{Vehicle Registration Tax (VRT) Benefits}

All motor vehicles entering a country should be registered within a specific period of time. According to the rules of the country, an amount of money will be charged as a tax called the registration tax. The procedure and amount of money differ among different EU countries and type of vehicles. BEVs are categorized as zero $\mathrm{CO}_{2}$ emission, and they are 
exempted from the VRT tax in Norway, Netherlands, Spain, Hungary, and Poland, while in the UK they also exempt zero-emission vehicles but with the price condition. Here, only vehicles with a price less than or equal to 40,000 pounds (47,000 euros). France exempts all vehicles under $120 \mathrm{~g} \mathrm{CO}_{2} / \mathrm{km}$ from this type of tax. Austria also exempts all cars with less than $90 \mathrm{~g} \mathrm{CO}_{2} / \mathrm{km}$ from paying VRT [43].

In an econometric analysis investigating the impact of fiscal policies on new passenger cars, Gerlagh et al. [44] submitted that a greater $\mathrm{CO}_{2}$ sensitivity of registration taxes would influence the purchase of more environmentally friendly vehicles. In addition, for countries like Denmark, where the vehicle registration tax is high, the outcome of the stated choice experiment by Mabit and Fosgerau [45] concluded that VRT benefits would boost the market adoption of alternative-fuel vehicles. However, just about half of the survey sample in Bjerkan et al. [41] considered VRT benefits critical to their BEV purchase decision.

\subsubsection{Ownership Tax (Circulation or Road Tax) Benefits}

Ownership tax is known by various names as a road tax or annual circulation tax. It is applied to all wheeled vehicles using public roads, and the amount is based on weight, fuel type, or $\mathrm{CO}_{2}$ emissions. In countries where the tax is based on fuel type or $\mathrm{CO}_{2}$ emissions, $\mathrm{BEVs}$ are granted a reduction in circulation taxes and total exemption in other places, as they have no tailpipe emission. For example, Norway's circulation tax is based on the fuel type. Both BEVs and PHEVs are granted a reduction, and they pay the least among other classes of vehicles. In Germany, Sweden, Netherlands, Austria, Portugal, and Hungary, all types of EV and plug-in are exempted from the annual circulation tax for five years starting from the date of registration. The UK also legislated a rule which exempts the zero-emission vehicles' value less than or equal to $40,000 \mathrm{GBP}$ (47,000 euros). Italy exempts the EV owner from annual circulation tax for five years from the date of registration. After that, they will benefit from a $75 \%$ reduction of the tax rates applied to the equivalent petrol vehicles in many regions. In contrast, France does not have a road tax at all.

Different studies have investigated the annual tax effect on PEV adoption. Hackbarth and Madlener [46] studied the impact of yearly tax exemption on alternative fuel vehicles (AFVs), which include BEVs. They concluded that removing this incentive would negatively impact the AFVs market in general, including BEVs.

A study [40] established that BEV potential buyers in Norway consider road tax discount/exemption as an important factor behind their decision to buy BEVs and impact the purchase decision of $49 \%$ of the BEV buyers. This result is consistent with the results of a study in the Netherlands [15], which concluded that a road tax exemption is an essential factor, and without them, the market will be negatively affected.

\subsubsection{Company Tax Benefits}

Companies or corporations that have BEVs in their fleet are often exempted from paying taxes on such vehicles. Company tax, also known as corporation tax, is a direct tax levied by authorities on the corporations. It is also referred to as income or capital tax, which is usually imposed at the national level or sometimes at the state or local levels. In Hungary and Austria, BEVs are exempt from the company car taxes. Norway and the UK reduce the taxes on the company cars, while Germany offsets the list price by 500 euros per unit of battery size, expressed in kilowatt-hour $(\mathrm{kWh})$. France applies different rules for this type of tax, according to which it is calculated based on two elements, namely the $\mathrm{CO}_{2}$ emission-based, estimated with a staggered approach, which exempts vehicles less than $60 \mathrm{~g} \mathrm{CO}_{2} / \mathrm{km}$, and the second component is based on environmental impact, which is very high for the old diesel vehicles while EVs pay only 20 euros per year. In Sweden, in addition to the purchase incentive, the tax is also reduced for the private usage of company cars.

While not many studies have directly investigated the motivation for BEV adoption by corporate fleet managers, an evidence [47] has attributed the share of BEVs in the Netherlands to the tax exemptions for company cars which are procured as a typical 
job benefit in many European countries. A recent survey with Swiss fleet managers had $56 \%$ of the respondents identifying the reduction of vehicle taxes as an important or very important policy instrument to motivate the electrification of the corporate fleet [48].

\subsubsection{Discounted/Free Parking}

Parking for free in public places for PEVs or at heavily discounted rates is one of the policy incentives offered to the user in different countries to encourage more potential buyers to switch to electric mobility. Various researches have addressed the effect of free parking incentives on the adoption of electromobility.

Different methodologies are used to study the effect of the discounted/free parking for PEVs, including statistical analyses, interviews, and surveys across different geographical locations, including the USA, Europe, and China. Statistical analysis conducted on the data gathered from the USA, Europe, and China [49], Norway [50,51], and Sweden [52], concluded that the PEVs and free parking are correlated, and the effect is more noticeable in urban areas. Moreover, stated preference studies in the USA [53], in Germany [46], and in China [54] inferred that free parking was an important incentive for some of the potential buyers.

As asserted in separate studies [41,55] involving PEV adopters in Norway, free parking is the second most important incentive. Nevertheless, other studies found that free/discounted parking is ineffective or has less significant impacts when compared to other types of stimuli in the PEVs market. For example, Krause et al. [53] found that free parking can encourage the potential buyer, but only $1.7 \%$ of the adopters were aware that the parking is free for the PEVs in their region, while other study [56] determined that purchase subsidy and infrastructure development were more important for the potential buyers.

\subsubsection{Free Access to Toll Roads}

Toll roads are also known as turnpikes or tollways. These roads are either owned by the government or privately owned, and access is granted based on the payment of a fee or toll. It is also considered a form of road pricing applied to roads to help with their construction and maintenance. The fees usually vary according to the vehicle's type, weight, and number of axles in the case of freight vehicles.

Electric vehicles are also a part of the road transportation system, although their number is still small compared to conventional vehicles. Toll roads are also used as an incentive for encouraging the market, where PEVs are granted access at no cost to these types of roads in some countries, to encourage more PEVs potential buyers and particularly BEVs adopters.

Bjerkan et al. [41], furthermore Figenbaum, and Kolbenstvedt [55] postulated that the toll road exemption is an important incentive that affects potential adopters' purchase decisions. Zhang et al. [57] also inferred in a stated preference survey conducted in Norway that exempting PEVs from toll roads would increase their chance of purchase. On the other hand, other study [50] could not find the relation between the PEV market and toll exemption. Huang et al. [36], similarly, were unable to establish the correlation between toll fee discounts for PEVs and purchase decisions. However, the effect of this incentive is mainly considered for HEVs and PHEVs, with BEVs being side-stepped. This is because toll roads are usually intercity highways, and BEVs are typically not considered for longdistance trips due to their limited ranges, especially if charging infrastructure along such routes are inadequate.

\subsection{Non-Financial Incentives}

At the other end of the spectrum, there are non-financial incentives, which are special privileges offered to EV users and potential adopters with no direct cost of provision borne directly by the user. These privileges are usually recurrent and enjoyed during the ownership of the vehicles until the enabling policies are changed, suspended, or reversed. 
The most notable types include charging infrastructure development and access to exclusive traffic lanes. Other incentives offered to the potential buyer, or actual EV user after the purchase or during the EV ownership, can be considered non-financial incentives if there is no actual physical payment or discount or exemption offered to user and adopters. They are recurrent during the lifetime of vehicle ownership, such as access to bus lanes or the development of infrastructure, including intracity (increasing the number of fast and slow charging points) and intercity (number of charging points per $100 \mathrm{~km}$ of the highway).

\subsubsection{Infrastructure Development}

To douse the range anxiety associated with EV usage, governments at different levels, apart from providing financial incentives for the installation of private charging equipment, also invest massively in the provision of charging infrastructure in public places within the urban area and on highway routes. While the provision of charging infrastructure is key for the market penetration of EVs, investigating the interdependence of the two is quite complex.

Studies undertaken to investigate the effect of infrastructure on plug-in electric vehicles (which include BEVs) have established a positive relationship between the market penetration levels and the number of charging stations through their statistical analysis of existing data [49,50,58-60]. Nevertheless, it is difficult to ascertain whether the provision of charging infrastructure is responsible for the boost in EV adoption or vice versa as this is a classic chicken and egg strategy problem. Supporting the argument that charging infrastructure has the potential to boost the sales of electric vehicles, a survey conducted across 20 countries had $42 \%$ of the study sample who are EV users opining that installation of a charging network on freeways is a factor positively affecting the adoption of EVs [56]. Similarly, stated preference surveys $[36,57,61]$ among potential EV adopters inferred that the development of charging infrastructure could reduce the range anxiety and consequently increase the probability of purchasing BEVs.

Other studies found that infrastructural investment is not effective in incentivizing electric vehicle adoption. Hardman and Tal [62] particularly studied the effect of infrastructure using data from in-depth interviews and found that public infrastructure provision in urban areas did not motivate the users of electric vehicles since most respondents mostly charge their vehicles at home, while others acknowledged workplace charging as an important factor behind their BEV adoption decision. Regardless of the interdependency, the availability of charging infrastructure remains a plus for BEV users.

However, to make charging infrastructure more effective in the drive for increased BEV market penetration, the focus of public charging station investments should shift away from urban areas to intercity highways and rural areas. This is in line with other recommendations $[36,63]$ as urban areas mostly have the more sustainable active and public transport alternatives, which are often unavailable in rural areas. Moreover, refocusing charging infrastructure to these areas would imply that BEVs will be more suited for longdistance intercity trips, thus making them attractive to rural residents whose commute range is more fitting to the discharge-recharge cycle of BEVs, and thereby allowing them to fully harness the lower operating cost potential of BEVs [64].

\subsubsection{Access to Restricted Traffic Lanes and Areas}

BEVs are granted access to restricted traffic lanes and areas, which include bus lanes, pedestrianized areas, and high occupancy vehicle (HOV) lanes (also known as carpool lane, diamond lane, 2+ lane, T2 or T3 lane) in some places during traffic rush hours only or round the clock. The exclusive access given to these vehicles in many cities has proven to be pivotal to market adoption [41,65-68]. While a few studies [50,69] could not find a significant correlation between market adoption and access to HOV and bus lanes, Kurani et al [70] argued that the benefit and impact of access to these exclusive lanes differ by geographical location depending on the traffic congestion level and the availability of these restrictive lanes for EV usage. Based on these studies, it can therefore be concluded 
that the effectiveness of this incentive largely depends on the traffic condition, congestion levels, and the market penetration level of EVs within the urban fleet.

\subsection{Disincentivising ICEVS}

While the incentives discussed so far have been targeted at providing benefits to BEV adopters, there are a couple of policy measures that do not offer direct utility for these users but instead focus on discouraging the proliferation of ICEVs. The application of these measures that reduce fossil fuel consumption and, by extension, lower GHG emissions has been indicated to positively affect electric vehicle market in general and BEVs in particular.

The increment in fuel prices is not necessarily due to the tax increase or any policy interferences. The global trend is more actively going towards more green energy and sustainable means of transport to reduce GHG emissions. Therefore, as a policy intervention, the fuel price in general increased. Increasing the fuel tax, fuel duty, or gasoline taxes are general measures to manage fuel consumption, emissions, or increase revenues. Although a disincentive for conventional vehicles, this increment could simultaneously be an effective incentive for PEVs in general and BEVs especially. This relationship was supported by the outcome of several research studies $[60,65,71]$. However, it should be noted that Adepetu et al. [58] could not get obtain any indication to posit that a hike in fuel prices can affect the market share of EVs.

Similarly, a vehicle ownership tax increment targeted at conventional vehicles for environmental reasons can influence BEV sales, as it reduces the cost-competitive advantage ICEVs might have over BEVs as the latter are often exempted from these tax increments. Whether it is intentional or not, this policy could affect the PEV market by increasing the operational costs of the conventional market. Besides, exempting the PEVs vehicles from such taxes might spur their demand [72].

\section{Discussion and Conclusions}

This study investigated a set of barriers that may hinder the wider adoption of BEVs worldwide. Among the factors considered, the high purchase cost (including the expensive battery technology and the market volatility of battery resources) is one of the main factors hindering market growth. The range and refueling time factors also negatively impact the market penetration. However, BEV users may act on them through conscious vehicle selection and travel planning. The extent of the impacts may vary across the countries, so the demographic, economic, geographical, and cultural nuances could affect these findings.

The authors investigated three main categories of incentivizing measures: financial incentives, non-financial incentives, and disincentives (towards ICEVs).

Insofar as social costs of ICEVs are not highly or totally internalized (see disincentivizing ICEVs), users tend to maintain their existing habits, favoring the less expensive technologies. Consequently, despite the various direct financial incentives that aim to reduce the purchase prices, they have only limited impacts on the market, so electric vehicles may remain the preferred choice of only higher income level users. Among the financial incentives, the most promising, indirect measures are rather linked to the usage of BEVs.

The non-financial incentives are special privileges for the BEV users. Among them, the charging infrastructure development for intercity traffic seems to be crucial towards market penetration, while it has less impact on the market of vehicles generally used for intracity traffic. The authors concluded that the expected impacts of non-financial measures are largely dependent on local conditions.

Disincentives for conventional vehicles may positively impact the BEV market, but this is only a secondary effect of policy measures towards greening the transportation and making it more sustainable.

The phases of evolution for electric vehicle markets will require different measures in time. While market intake shall instead focus on direct financial incentives and nonfinancial incentives, later, the depth of penetration will depend on indirect financial incentives and non-financial incentives, while in the long term, the ICEV disincentives may 
stand in focus. Besides the disincentives, the financial and non-financial measures are expected to be phased out in the long term [73]. While the different incentives may have various impacts on the BEV market, additional incentives may supplement or even boost these impacts, especially in making synergies between the market phase depending on incentive category. Moreover, the bulk of the incentives are geared towards the traditional business model of private car ownership. Thus, targeting novel and innovative business models such as the mobility as a service (MaaS) business models will play a significant role in fully harnessing the potential of BEVs.

Providing clean and green transport through an economically efficient and socially progressive approach without compromising the mobility needs of the present and future generations is the goal of sustainable transport. Of course, achieving sustainable transport in urban areas will imply reducing the overall automobile dependency. However, it is fundamental to understand that vehicle electrification in its truest form powered by clean energy will play a significant role in that transition and cannot be discarded [74]. BEVs are gradually gaining market penetration, although slower than their hybrid counterparts, despite the environmental demerits of the latter [25]. The pace can be accelerated through purposive policy strategies to make BEVs the basic EV choice, primarily through nonfinancial market incentives and public environmental education. This needs to be reinforced and explored further $[75,76]$.

Nevertheless, decision-makers may need to find the balance between the different categories as excessive incentivizing, due to extra burdens on public funds and unwanted growth in vehicle fleets, may lead to counter-productive consequences in the long term. Therefore, electric mobility incentives have to be implemented as part an integrated approach with other urban mobility actions and measures, including improving public transport, encouraging active mobility, and adopting urban vehicle access regulations, and also in tandem with all stakeholders and institutions within and beyond the automotive sector and urban planning ecosystem. This is key for the sustainability of future transportation.

The findings of this study make it clear that there are positive impacts and interactions of the BEV market incentives. However, the local socio-demographic and socio-economic factors influence their extent. Consequently, a comprehensive statistical analysis and sophisticated qualification of market incentives across the most prominent countries have to be undertaken to obtain a deeper understanding of attributes for such measures and a more specific set of policy measures for decision-makers.

Author Contributions: Conceptualization, H.K.Y.A.-Z.; supervision, F.M.; writing-original draft, G.A.O. All authors have read and agreed to the published version of the manuscript.

Funding: This research received no external funding.

Institutional Review Board Statement: Not applicable.

Informed Consent Statement: Not applicable.

Data Availability Statement: No new data were created or analyzed in this study. Data sharing is not applicable to this article.

Acknowledgments: The research was supported by OTKA-K20-134760-Heterogeneity in user preferences and its impact on transport project appraisal led by Adam TOROK.

Conflicts of Interest: The authors declare no conflict of interest.

\section{References}

1. United Nations. Framework Convention on Climate Change-Adoption of the Paris Agreement. In Proceedings of the 21st Conference of the Parties, Paris, France, 12 December 2015.

2. Lah, O.; Alveano, S.; Arioli, M.; Chesterton, V.; Sdoukopoulos, L. Sustainable urban mobility solutions for Asia, Latin America and the Mediterranean region. In Sustainable Urban Mobility Pathways; Lah, O., Ed.; Elsevier: Amsterdam, The Netherlands, 2019; pp. 23-63. [CrossRef]

3. The International Energy Agency. Tracking Transport 2020, IEA. 2020. Available online: https://www.iea.org/reports/trackingtransport-2020 (accessed on 13 April 2021). 
4. Lund, P.D.; Lindgren, J.; Mikkola, J.; Salpakari, J. Review of energy system flexibility measures to enable high levels of variable renewable electricity. Renew. Sustain. Energy Rev. 2015, 45, 785-807. [CrossRef]

5. Shokrzadeh, S.; Bibeau, E. Sustainable integration of intermittent renewable energy and electrified light-duty transportation through repurposing batteries of plug-in electric vehicles. Energy 2016, 106, 701-711. [CrossRef]

6. Salpakari, J.; Rasku, T.; Lindgren, J.; Lund, P.D. Flexibility of electric vehicles and space heating in net zero energy houses: An optimal control model with thermal dynamics and battery degradation. Appl. Energy 2017, 190, 800-812. [CrossRef]

7. Wu, X.; Hu, X.; Teng, Y.; Qian, S.; Cheng, R. Optimal integration of a hybrid solar-battery power source into smart home nanogrid with plug-in electric vehicle. J. Power Sources 2017, 363, 277-283. [CrossRef]

8. Boglietti, S.; Barabino, B.; Maternini, G. Survey on e-Powered Micro Personal Mobility Vehicles: Exploring Current Issues towards Future Developments. Sustainability 2021, 13, 3692. [CrossRef]

9. Samaras, C.; Meisterling, K. Life cycle assessment of greenhouse gas emissions from plug-in hybrid vehicles: Implications for policy. Environ. Sci. Technol. 2008, 42, 3170-3176. [CrossRef]

10. Holdway, A.R.; Williams, A.R.; Inderwildi, O.R.; King, D.A. Indirect emissions from electric vehicles: Emissions from electricity generation. Energy Environ. Sci. 2010, 3, 1825-1832. [CrossRef]

11. Michalek, J.J.; Chester, M.; Jaramillo, P.; Samaras, C.; Shiau, C.S.N.; Lave, L.B. Valuation of plug-in vehicle life-cycle air emissions and oil displacement benefits. Proc. Natl. Acad. Sci. USA 2011, 108, 16554-16558. [CrossRef]

12. Plötz, P.; Moll, C.; Bieker, G.; Mock, P. From lab-to-road: Real-world fuel consumption and $\mathrm{CO}_{2}$ emissions of plug-in hybrid electric vehicles. Environ. Res. Lett. 2021, 16, 54078. [CrossRef]

13. Traut, E.J.; Cherng, T.C.; Hendrickson, C.; Michalek, J.J. US residential charging potential for electric vehicles. Transp. Res. Part D Transp. Environ. 2013, 25, 139-145. [CrossRef]

14. Hidrue, M.K.; Parsons, G.R.; Kempton, W.; Gardner, M.P. Willingness to pay for electric vehicles and their attributes. Resour. Energy Econ. 2011, 33, 686-705. [CrossRef]

15. Hoen, A.; Koetse, M.J. A choice experiment on alternative fuel vehicle preferences of private car owners in the Netherlands. Transp. Res. Part A Policy Pract. 2014, 61, 199-215. [CrossRef]

16. Biresselioglu, M.E.; Kaplan, M.D.; Yilmaz, B.K. Electric mobility in Europe: A comprehensive review of motivators and barriers in decision making processes. Transp. Res. Part A Policy Pract. 2018, 109, 1-13. [CrossRef]

17. Boulanger, A.G.; Chu, A.C.; Maxx, S.; Waltz, D.L. Vehicle electrification: Status and issues. Proc. IEEE 2011, 99, 1116-1138. [CrossRef]

18. Haddadian, G.; Khodayar, M.; Shahidehpour, M. Accelerating the Global Adoption of Electric Vehicles: Barriers and Drivers. Electr. J. 2015, 28, 53-68. [CrossRef]

19. Jozwicka, M.; Hacker, F.; Hülsmann, F.; Minnich, L.; Purwanto, J. Electric Vehicles in Europe; European Environment Agency: Copenhagen, Denmark, 2016. [CrossRef]

20. Speirs, J.; Contestabile, M. The future of lithium availability for electric vehicle batteries. In Behaviour of Lithium-Ion Batteries in Electric Vehicles; Pistoia, G., Liaw, B., Eds.; Springer: New York, NY, USA, 2018; pp. 35-57. [CrossRef]

21. United States Geological Survey. Mineral Commodity Summaries; Government Printing Office: Washington, DC, USA, 2009.

22. Tahil, W. The Trouble with Lithium 2-Under the Microscope; Meridian International Research: Martainville, France, 2008.

23. Nykvist, B.; Nilsson, M. Rapidly falling costs of battery packs for electric vehicles. Nat. Clim. Chang. 2015, 5, 329-332. [CrossRef]

24. Un-Noor, F.; Padmanaban, S.; Mihet-Popa, L.; Mollah, M.N.; Hossain, E. A comprehensive study of key electric vehicle (EV) components, technologies, challenges, impacts, and future direction of development. Energies 2017, 10, 1217. [CrossRef]

25. The International Energy Agency. Global EV Outlook 2021, IEA. 2021. Available online: https://www.iea.org/reports/global-evoutlook-2021 (accessed on 13 April 2021).

26. Samadani, E.; Fraser, R.; Fowler, M. Evaluation of air conditioning impact on the electric vehicle range and li-ion battery life. $S A E$ Tech. Pap. 2014. [CrossRef]

27. Meyer, J.J.; Lustbader, J.; Agathocleous, N.; Vespa, A.; Rugh, J.; Titov, G. Range Extension Opportunities while Heating a Battery Electric Vehicle; The National Renewable Energy Laboratory: Golden, CO, USA, 2018. [CrossRef]

28. Sierzchula, W.; Bakker, S.; Maat, K.; Van Wee, B. The influence of financial incentives and other socio-economic factors on electric vehicle adoption. Energy Policy 2014, 68, 183-194. [CrossRef]

29. Chen, C.F.; de Rubens, G.Z.; Noel, L.; Kester, J.; Sovacool, B.K. Assessing the socio-demographic, technical, economic and behavioral factors of Nordic electric vehicle adoption and the influence of vehicle-to-grid preferences. Renew. Sustain. Energy Rev. 2020, 121, 109692. [CrossRef]

30. Carley, S.; Krause, R.M.; Lane, B.W.; Graham, J.D. Intent to purchase a plug-in electric vehicle: A survey of early impressions in large US cites. Transp. Res. Part D Transp. Environ. 2013, 18, 39-45. [CrossRef]

31. Kahn, M.E. Do greens drive Hummers or hybrids? Environmental ideology as a determinant of consumer choice. J. Environ. Econ. Manag. 2007, 54, 129-145. [CrossRef]

32. Campbell, A.R.; Ryley, T.; Thring, R. Identifying the early adopters of alternative fuel vehicles: A case study of Birmingham, United Kingdom. Transp. Res. Part A Policy Pract. 2012, 46, 1318-1327. [CrossRef]

33. Wang, N.; Tang, L.; Pan, H. A global comparison and assessment of incentive policy on electric vehicle promotion. Sustain. Cities Soc. 2019, 44, 597-603. [CrossRef] 
34. Zhang, X.; Xie, J.; Rao, R.; Liang, Y. Policy incentives for the adoption of electric vehicles across countries. Sustainability 2014, 6, 8056-8078. [CrossRef]

35. Münzel, C.; Plötz, P.; Sprei, F.; Gnann, T. How large is the effect of financial incentives on electric vehicle sales?-A global review and European analysis. Energy Econ. 2019, 84, 104493. [CrossRef]

36. Huang, Y.; Qian, L. Consumer preferences for electric vehicles in lower tier cities of China: Evidences from south Jiangsu region. Transp. Res. Part D Transp. Environ. 2018, 63, 482-497. [CrossRef]

37. Kley, F.; Wietschel, M.; Dallinger, D. Evaluation of European Electric Vehicle Support Schemes; Fraunhofer Institute for Systems and Innovation Research ISI: Karlsruhe, Germany, 2010.

38. Liao, F.; Molin, E.; van Wee, B. Consumer preferences for electric vehicles: A literature review. Transp. Rev. 2017, 37, 252-275. [CrossRef]

39. Huang, J.; Leng, M.; Liang, L.; Liu, J. Promoting electric automobiles: Supply chain analysis under a government's subsidy incentive scheme. IIE Trans. 2013, 45, 826-844. [CrossRef]

40. Figenbaum, E. Perspectives on Norway's supercharged electric vehicle policy. Environ. Innov. Soc. Transit. 2017, 25, 14-34. [CrossRef]

41. Bjerkan, K.Y.; Nørbech, T.E.; Nordtømme, M.E. Incentives for promoting battery electric vehicle (BEV) adoption in Norway. Transp. Res. Part D Transp. Environ. 2016, 43, 169-180. [CrossRef]

42. Brand, C.; Anable, J.; Tran, M. Accelerating the transformation to a low carbon passenger transport system: The role of car purchase taxes, feebates, road taxes and scrappage incentives in the UK. Transp. Res. Part A Policy Pract. 2013, 49, 132-148. [CrossRef]

43. European Alternative Fuels Observatory. Available online: https://www.eafo.eu/countries/european-union/23640/summary (accessed on 22 April 2021).

44. Gerlagh, R.; van den Bijgaart, I.; Nijland, H.; Michielsen, T. Fiscal Policy and $\mathrm{CO}_{2}$ Emissions of New Passenger Cars in the EU. Environ. Resour. Econ. 2018, 69, 103-134. [CrossRef]

45. Mabit, S.L.; Fosgerau, M. Demand for alternative-fuel vehicles when registration taxes are high. Transp. Res. Part D Transp. Environ. 2011, 16, 225-231. [CrossRef]

46. Hackbarth, A.; Madlener, R. Consumer preferences for alternative fuel vehicles: A discrete choice analysis. Transp. Res. Part D Transp. Environ. 2013, 25, 5-17. [CrossRef]

47. Kok, R. Six years of $\mathrm{CO}_{2}$-based tax incentives for new passenger cars in The Netherlands: Impacts on purchasing behavior trends and $\mathrm{CO}_{2}$ effectiveness. Transp. Res. Part A Policy Pract. 2015, 77, 137-153. [CrossRef]

48. Vuichard, P. Electrifying the company car: Identifying hard and soft barriers among fleet managers in Switzerland. Energy Res. Soc. Sci. 2021, 77, 102098. [CrossRef]

49. Ajanovic, A.; Haas, R. Dissemination of electric vehicles in urban areas: Major factors for success. Energy 2016, 115, 1451-1458. [CrossRef]

50. Mersky, A.C.; Sprei, F.; Samaras, C.; Qian, Z.S. Effectiveness of incentives on electric vehicle adoption in Norway. Transp. Res. Part D Transp. Environ. 2016, 46, 56-68. [CrossRef]

51. Aasness, M.A.; Odeck, J. The increase of electric vehicle usage in Norway-Incentives and adverse effects. Eur. Transp. Res. Rev. 2015, 7, 1-8. [CrossRef]

52. Egnér, F.; Trosvik, L. Electric vehicle adoption in Sweden and the impact of local policy instruments. Energy Policy 2018, 121, 584-596. [CrossRef]

53. Krause, R.M.; Carley, S.R.; Lane, B.W.; Graham, J.D. Perception and reality: Public knowledge of plug-in electric vehicles in 21 US cities. Energy Policy 2013, 63, 433-440. [CrossRef]

54. Wang, N.; Tang, L.; Pan, H. Effectiveness of policy incentives on electric vehicle acceptance in China: A discrete choice analysis. Transp. Res. Part A Policy Pract. 2017, 105, 210-218. [CrossRef]

55. Figenbaum, E.; Kolbenstvedt, M. Learning from Norwegian Battery Electric and Plug-In Hybrid Vehicle Users; Transportøkonomisk Institutt: Oslo, Norway, 2016.

56. Lieven, T. Policy measures to promote electric mobility-A global perspective. Transp. Res. Part A Policy Pract. 2015, 82, 78-93. [CrossRef]

57. Zhang, Y.; Qian, Z.S.; Sprei, F.; Li, B. The impact of car specifications, prices and incentives for battery electric vehicles in Norway: Choices of heterogeneous consumers. Transp. Res. Part C Emerg. Technol. 2016, 69, 386-401. [CrossRef]

58. Adepetu, A.; Keshav, S.; Arya, V. An agent-based electric vehicle ecosystem model: San Francisco case study. Transp. Policy 2016, 46, 109-122. [CrossRef]

59. Javid, R.J.; Nejat, A. A comprehensive model of regional electric vehicle adoption and penetration. Transp. Policy 2017, 54, 30-42. [CrossRef]

60. Wee, S.; Coffman, M.; La Croix, S. Do electric vehicle incentives matter? Evidence from the 50 US states. Res. Policy 2018, 47, 1601-1610. [CrossRef]

61. Egbue, O.; Long, S. Barriers to widespread adoption of electric vehicles: An analysis of consumer attitudes and perceptions. Energy Policy 2012, 48, 717-729. [CrossRef]

62. Hardman, S.; Tal, G. Exploring the decision to adopt a high-end battery electric vehicle: Role of financial and non-financial motivations. Transp. Res. Rec. 2016, 2572, 20-27. [CrossRef] 
63. Newman, D.; Wells, P.; Donovan, C.; Nieuwenhuis, P.; Davies, H. Urban, sub-urban or rural: Where is the best place for electric vehicles? Int. J. Automot. Technol. Manag. 2014, 14, 306-323. [CrossRef]

64. Nieuwenhuis, P.; Cipcigan, L.; Sonder, H.B. The electric vehicle revolution. In Future Energy; Elsevier: Amsterdam, The Netherlands, 2020; pp. 227-243. [CrossRef]

65. Narassimhan, E.; Johnson, C. The role of demand-side incentives and charging infrastructure on plug-in electric vehicle adoption: Analysis of US States. Environ. Res. Lett. 2018, 13, 74032. [CrossRef]

66. Sheldon, T.L.; DeShazo, J.R. How does the presence of HOV lanes affect plug-in electric vehicle adoption in California? A generalized propensity score approach. J. Environ. Econ. Manag. 2017, 85, 146-170. [CrossRef]

67. Jenn, A.; Springel, K.; Gopal, A.R. Effectiveness of electric vehicle incentives in the United States. Energy Policy 2018, 119, 349-356. [CrossRef]

68. Fearnley, N.; Pfaffenbichler, P.; Figenbaum, E.; Jellinek, R. E-Vehicle Policies and Incentives: Assessment and Recommendations; Transportøkonomisk Institutt: Oslo, Norway, 2015.

69. Clinton, B.; Brown, A.; Davidson, C.; Steinberg, D. Impact of Direct Financial Incentives in the Emerging Battery Electric Vehicle Market: A Preliminary Analysis; The National Renewable Energy Laboratory: Golden, CO, USA, 2015.

70. Kurani, K.S.; Caperello, N.; TyreeHageman, J.; Davies-Shawhyde, J. I am not an environmental wacko! Getting from early plug-in vehicle owners to potential later buyers. In Proceedings of the Transportation Research Board 94th Annual Meeting, Washington, DC, USA, 11-15 January 2015.

71. Kangur, A.; Jager, W.; Verbrugge, R.; Bockarjova, M. An agent-based model for diffusion of electric vehicles. J. Environ. Psychol. 2017, 52, 166-182. [CrossRef]

72. Yan, S. The economic and environmental impacts of tax incentives for battery electric vehicles in Europe. Energy Policy 2018, 123, 53-63. [CrossRef]

73. Lu, T.; Yao, E.; Jin, F.; Pan, L. Alternative Incentive Policies against Purchase Subsidy Decrease for Battery Electric Vehicle (BEV) Adoption. Energies 2020, 13, 1645. [CrossRef]

74. Nilsson, M.; Nykvist, B. Governing the electric vehicle transition-Near term interventions to support a green energy economy. Appl. Energy 2016, 179, 1360-1371. [CrossRef]

75. Karytsas, S.; Theodoropoulou, H. Socioeconomic and demographic factors that influence publics' awareness on the different forms of renewable energy sources. Renew. Energy 2014, 71, 480-485. [CrossRef]

76. Beck, M.J.; Rose, J.M.; Greaves, S.P. I can't believe your attitude: A joint estimation of best worst attitudes and electric vehicle choice. Transportation 2017, 44, 753-772. [CrossRef] 